Hajduova, Z., Coronicova Hurajova, J., Smorada, M., \& Srenkel, L (2021). Competitiveness of the Selected Countries of the EU with a Focus on the Quality of the Business Environment. Journal of Competitiveness, 13(4), 43-59. https://doi.org/10.7441/joc.2021.04.03

\title{
Competitiveness of the Selected Countries of the EU with a Focus on the Quality of the Business Environment
}

\author{
- Zuzana Hajduova, Jana Coronicova Hurajova, Marian Smorada, Ludovit \\ Srenkel
}

\begin{abstract}
The business environment and entrepreneurship are important elements in the economic growth of each country. The better the business environment a given country offers, the more attractive the country is for small and large companies as well as for private entrepreneurs. A high level of business competitiveness can help a country secure economic growth, especially after overcoming a crisis such as the COVID-19 pandemic. Many institutions focus on the measurement of the business environment using indices to evaluate its quality. The main goal of the present study is to evaluate the quality of the business environment through multicriteria analysis. For the period from 2018 to 2020, the data were analysed by using seven selected indices of the weighted sum approach (WSA) and the technique for order preference by similarity to ideal solution (TOPSIS) methods. The research sample included all EU countries that joined the EU at the same time in 2004. The processing of analytical data was gradually implemented by using descriptive statistics and multicriteria evaluation methods. The methods used in the multicriteria evaluation of variants determined the rankings of the individual variants in terms of the selected criteria using entropy. We concluded that the efficiency of the business environments in Cyprus, the Czech Republic, Estonia, Hungary, Poland, Latvia, Lithuania, Slovakia and Slovenia are below the EU average. Within this group of countries, Estonia, Malta and Slovenia have seen the largest regeneration of their business environment since having joined the EU.
\end{abstract}

Keywords: business environment, competitiveness, multicriteria analysis, TOPSIS, WS A

JEL Classification: C44, C61, L21

Received: April, 2021

1st Revision: October, 2021

Accepted: October, 2021

\section{INTRODUCTION}

Based on economic theory, the quality of the business environment is considered to be the country's ability to provide entrepreneurs with a sufficient level of freedom and low taxes, and the country's ability to produce products cheaply and efficiently with minimal production 
inputs and high labour productivity (Mankiw, 2020). Low innovation capacity, corruption, political instability, resolving insolvency, and the judiciary are attributes that are monitored by individual indices. We can consider the governments of individual countries as companies that transform inputs into outputs in an environment similar to the corporate environment. Country governments adopt policy conclusions that have a direct and indirect impact on the business environment (Bertelli, 2016). These parameters influence the value of the quantified index, which is assigned in a particular year for the chosen country. The monitored indices have various constructions and use different variables and types of data. If the set of business quality indices in which the countries are assessed is numerous, then it is difficult to decide on the position of a given country within the examined set of countries. The reason is that by using the selected indices, one country may achieve excellent results, but by changing the selection of indices, another country may overtake it. The multicriteria analysis used in this paper as a data processing tool not only identifies the compromise option, i.e., the country or countries that rank first in the overall evaluation, but it also shows how much the country was able to compete with other countries selected and how effective the country's decisions were in improving the quality of businesses and the business environment. With the help of this analysis, it is possible to evaluate the progress within the business environment from a comprehensive point of view regarding the elimination of incorrect data, data normalisation and sensitivity analysis. It is in the EU's interest to support the prosperity and economic growth of its members, among which a plan presented in 2013 for stimulating the business potential of countries was established. For the selection of the compared indices, the areas represented in the monitored data were chosen. These areas are administrative burdens, business legislation, financial burdens, technological progress, education, and quality of life. Based on the process used and results obtained, our study points to a new perspective regarding the level of the business environment in relation to the competitiveness of a country. We examined a group of countries that joined the EU in the same year. The structure of the present study is based on the theoretical foundation of foreign literature, which currently deals with the subject. A properly functioning business environment provides a motive for people to expand business, improves competitiveness and economic performance, increases the business potential of the country, and increases the living standards of the population. The business environment is also affected by the COVID-19 pandemic, so it is very important to identify the current status of the business environment and compare it with the parameters that have or will reflect the impact of COVID-19 on the competitiveness of countries.

This work analyses the quality of the business environment of the ten countries that joined the EU in the same year. The aim of this analysis is to determine how the position of the selected countries has changed in the two years from 2018 to 2020 and whether Slovakia and other selected countries have increased their competitiveness. For this purpose, multicriteria analysis was selected as the main method, which allows us to process a larger number of indicators representing the criteria on which the analysis is based. 


\section{THEORETICAL BACKGROUND}

The business environment has a direct impact on the level and fluctuations in demand for the company's products. This environment is formed by factors at the macro level as well as at the micro-level. The quality of the business environment is evaluated on the basis of variables such as GDP, unemployment rate, foreign direct investment, and public debt (Bjørnskov et al., 2016; Metzker et al., 2020; Čižo et al., 2020). The large quantity of related research conducted globally is confirmation of the importance of business issues in today's economy. In important studies, the rate of business activity is considered to be one of the key determinants of economic development (Urbano et al., 2016; Remeikiene et al., 2020). The systematic review of empirical research on the impact of entrepreneurship on economic, social and environmental well-being is summarised in several studies (Block et al., 2019; Halasi et al., 2019; Hao et al., 2020). Some authors have found that entrepreneurial activity may vary according to the country's level of economic development. According to their research, entrepreneurship has a positive impact on economic growth in highly developed countries, while the opposite, negative effect has been observed in less developed countries (Altuntas et al., 2018; Kotaskova et al., 2018). Research studies have confirmed that the government is an important factor in determining the pace of economic growth in countries. Entrepreneurial activity is fundamentally influenced by the economic and socio-cultural system in which entrepreneurship develops (Fuentelsaz et al., 2015; Mrozewski et al., 2017; Kasseeah et al., 2016). Kasseeah (2016) revealed that entrepreneurial activity is an important factor contributing to the speed of economic development. Financial development, especially capital markets in the form of financial goods, greatly contributes to the faster growth of the country's wealth because companies have more accessible foreign sources of financing. Regulatory barriers to entry for new businesses do not have a negative impact on corrupt countries but, conversely, do have a negative impact on less corrupt countries, meaning that corruption has a positive impact on business development. Importantly, a high degree of regulation and a large number of procedures required to set up a business will determine the entry of new entrepreneurs, but it depends on the industry (Noja et al., 2016). State institutions help to define standards in the business environment and to control or limit the economic behaviour of individuals, which can have important implications for long-term economic development. A key area is the labour market itself, which regulates employment conditions and the workforce in the area. The company needs to avoid stagnation. Technological change linked to innovation needs to be constantly monitored. Numerous empirical studies have focused on the role of innovation spending (especially $R \& D$ ) as a source of progress (Li et al., 2020). There are also a number of qualitative or quantitative criteria for deciding on the quality of the business environment. The business environment is a dynamically developing environment with various factors (Anyakoha, 2019; Li et al., 2019; Durda, 2018). The SME segment forms the basis of the market economy, employment, value-added or international trade and is a prerequisite for stable progress in the global economy (Zauskova \& Reznícková, 2020). They are a source of jobs that create entrepreneurship and contribute to innovation and economic growth. (Lechman, 2019; Belas et al., 2020). Innovation is the crucial element of a knowledge-based economy because the creation, exchange and market success via innovation are the sources of growth of many economic indicators and prosperity of society (Mura et al., 2018; Virglerova et al., 2020). 
Research and spending play a key role in determining differences in productivity between firms and productivity developments at the firm level over time. Although not all innovations are the result of research and development activities alone, knowledge is the most important factor in developing innovation. Knowledge companies enable the effective exchange of knowledge between research institutions and companies and provide a favourable business environment for the creation of new knowledge and the development and commercialisation of innovations (Lewandowska et al., 2018).

\section{RESEARCH OBJECTIVE, METHODOLOGY AND DATA}

The main objective of this work is to assess the environmental performance of selected EU countries based on empirical data through quantitative methods. Quality of life, environment, the environmental performance of countries and sustainability are supported by several theories. The quantification of aspects of these areas is handled through the K1 - K7 indices. These indices assess the correlation between environmental and economic indicators with respect to indicators related to the quality of life.

This thesis focuses on measuring the environmental performance of selected EU countries in the context of economic growth. The selection of appropriate environmental and economic indicators and the analysis of their interdependence helps to search for causal relationships. The identification and interconnectedness of the development of economic indicators linked to the trend of environmental indicators is a management theme and a tool for the effective functioning of environmental and energy policy.

Multicriteria analysis is based on a systematic procedure of input data processing, which allows for the evaluation of the selected research objects based on predetermined criteria and objectives. This method of data processing and evaluation is particularly suitable in situations where the objects being monitored and evaluated occupy an ambiguous order based on the selected criteria and where the number of important evaluation criteria causes ambiguity in the decision (Vakilipour, 2021; Ture, 2019; Marti, 2021; Feneri, 2015). For example, in a situation where according to one criterion, an ideal variant is an object that differs from the ideal variant determined by another criterion. The result of the multicriteria analysis is the identification of an ideal variant or a set of variants, or if none exist, then the identification of the objects that are closest to the ideal variant. A by-product of the multicriteria analysis is the ranking of variants from the best to the worst, which can also be a point of interest.

The subject of this paper is the study and the evaluation of the countries that joined the EU together with Slovakia in 2004. Those ten countries are as follows: Cyprus, Czech Republic, Estonia, Hungary, Latvia, Lithuania, Malta, Poland, Slovak Republic and Slovenia. These ten countries were evaluated according to seven indicators. These seven indicators represent the seven criteria, and the ten selected countries represent the ten variants in the multicriteria analysis described and evaluated in this work (OECD, 2021).

The criteria to evaluate the considered variants are:

K1 - Index of Economic Freedom, 
K2 - Global Competitiveness Index,

K3 - Doing Business

K4 - Corruption Perception Index,

K5 - Index of Social Progress,

K6 - Index Legatum Prosperity,

K7 - Environmental Performance Index.

There are several ways to determine the weight of the criteria in multicriteria analysis. These include the scoring method, the Fuller triangle, and the Saaty method. These, as well as some additional methods, are based on subjective evaluation, so it is necessary to know the preferences of the person for whom the analysis is intended. The aim of this paper is to objectively evaluate the countries described above; therefore, none of the methods mentioned was used. In contrast, to ensure an objective evaluation, two other more appropriate methods were chosen for determining the weights of the criteria. The first method is the equal weight method. With this method, each of the criteria is given the same weight, namely, 1: the number of criteria. In this case, the value is $1 / 7$, as there are seven criteria under consideration. The second method is the entropy method, which is used in situations where the evaluator does not know or cannot determine the criteria preferences. To gain the weights of the criteria by the entropy method, the following procedure is used:

- to transform the criterion matrix $\mathrm{Y}=\left(\mathrm{y}_{\mathrm{ij}}\right)$ of type $\mathrm{m} \times \mathrm{n}$ created of input data to an auxiliary matrix $\mathrm{Q}=\left(\mathrm{q}_{\mathrm{ij}}\right)$ using the following formula (Chen, 2019; Akram et al., 2019):

$\mathrm{q}_{i j}=\frac{y_{i j}}{\sum_{i=1}^{m} y_{i j}}$,

- to calculate the entropy $\mathrm{E}_{\mathrm{j}}$ for each of the considered criteria:

$E_{j}=-\frac{1}{\ln m} \sum_{i=1}^{m} q \ln q_{i j}$,

- calculate $\mathrm{T}_{\mathrm{j}}=1-\mathrm{E}_{\mathrm{j}}$ and use these values to determine the weight $\mathrm{w}_{\mathrm{j}}$ of the criterion $\mathrm{K}_{\mathrm{j}}$ as follows (Liang \& Xu, 2017; Zeng et al., 2020):

$w_{j}=\frac{T_{j}}{\sum_{j=1}^{n} T_{j}} ; j=1,2, \ldots, n$.

For better objectivity, more than one method is typically used, and the results thus obtained can be compared with each other. If they agree, the evaluator has a better idea of the solution to the problem and more certainty in choosing the appropriate option. Additionally, in this paper, two methods were used to determine the order of variants, namely, the weighted sum method (WSA) and the TOPSIS method.

The weighted sum method starts with the criterion matrix $Y=\left(y_{i j}\right)$. Subsequently, in each column of the matrix $\mathrm{Y}$, the best value and the worst value are found, and a new matrix $U=\left(\mathrm{u}_{\mathrm{ij}}\right)$ is created according to the following formula:

$u_{i j}=\frac{y_{i j}-d_{j}}{h_{j}-d_{j}} ; i=1,2, \ldots, m ; j=1,2, \ldots, n$. 
The value of $\mathrm{u}_{\mathrm{ij}}$ expresses the benefit of the $\mathrm{i}$-th variant with respect to the $\mathrm{j}$-th criterion. Furthermore, using the normalised weights, the values of the aggregate utility function are determined for each variant, with the best variant having the highest value of the given aggregate utility function (Triantaphyllou, 2000):

$u_{i}=\sum_{j=1}^{n} w_{j} u_{i j}$.

The TOPSIS method is the Technique for Order Preference by Similarity to Ideal Solution. This method is based on the principle of minimising the distance from the ideal variant, where the best variant is considered to be the one closest to the ideal variant and at the same time furthest from the basal variant. Finding the best variant or arranging the variants according to rank is the output of this method. TOPSIS consists of the following several steps. First, it is necessary to convert all criteria to maximisation, which means to ensure that a higher value of the given criteria means a better variant. This can be done by subtracting from the highest value of the criterion the corresponding value of the variant according to this criterion. Subsequently, the construction of the normalised matrix $\mathrm{R}=\left(\mathrm{r}_{\mathrm{ij}}\right)$ is done according to the formula (Chen \& Hwang, 1992):

$r_{i j}=\frac{y_{i j}}{\sqrt{\sum_{i=1}^{m}\left(y_{i j}\right)^{2}}} ; i=1,2, \ldots, m ; j=1,2, \ldots, n$.

Next, the matrix $\mathrm{R}$ is converted to the matrix $\mathrm{W}=\left(\mathrm{w}_{\mathrm{ij}}\right)$ by multiplying each element of the matrix $\mathrm{R}$ by the weight of the relevant criterion. Subsequently, the ideal variant and the basal variant are found. The ideal variant $b=\left(b_{1}, b_{2}, \ldots, b_{n}\right)$ is a vector formed from the maximum values in each column of the matrix $W$, and the negative ideal variant $z=\left(z_{1}, z_{2}, \ldots, z_{n}\right)$ is a vector formed from the minimum values in each column of the matrix W. The distance from the ideal variant and the distance from the negative ideal variant are calculated according to the formula:

$$
\begin{aligned}
& d_{i}^{+}=\sqrt{\sum_{j=1}^{n}\left(w_{i j}-b_{j}\right)^{2}} \\
& d_{i}^{-}=\sqrt{\sum_{j=1}^{n}\left(w_{i j}-z_{j}\right)^{2}} \\
& c_{i}=\frac{d_{i}^{-}}{d_{i}^{+}+d_{i}^{-}}
\end{aligned}
$$

The lower the value of the relative indicator, the closer the given variant is to the negative ideal variant.

\section{RESULTS AND DISCUSSION}

The main goal of this work is to determine the position of the selected countries in the two monitored periods, namely, in 2018 and 2020. The countries were evaluated according to seven important indicators that represent the given criteria in the preformed multicriteria analysis. TOPSIS and WSA methods were used for both examined periods. Each of these two methods was applied twice to both years, depending on the determination of the weights of the given 
criteria. Table 1 presents the normalised criterion matrix obtained from the input data gained for 2018.

Tab. 1 - Normalised criterion matrix, 2018. Source: own research

\begin{tabular}{|l|l|l|l|l|l|l|l|}
\hline Country & K1 & K2 & K3 & K4 & K5 & K6 & K7 \\
\hline CYPRUS & 0.30413 & 0.30554 & 0.30044 & 0.32929 & 0.32013 & 0.02667 & 0.33737 \\
\hline CZECH R. & 0.33288 & 0.33162 & 0.31990 & 0.33561 & 0.32697 & 0.42685 & 0.31450 \\
\hline ESTONIA & 0.35348 & 0.32976 & 0.33890 & 0.34774 & 0.32245 & 0.48021 & 0.29884 \\
\hline HUNGARY & 0.29920 & 0.29948 & 0.27146 & 0.3094 & 0.30939 & 0 & 0.3021 \\
\hline LATVIA & 0.33015 & 0.30833 & 0.33244 & 0.29728 & 0.30607 & 0.05335 & 0.30725 \\
\hline LITHUAN. & 0.33778 & 0.31253 & 0.33500 & 0.2835 & 0.3161 & 0.24010 & 0.32217 \\
\hline MALTA & 0.30727 & 0.32044 & 0.32428 & 0.34623 & 0.30584 & 0.50689 & 0.33690 \\
\hline POLAND & 0.30727 & 0.31765 & 0.30363 & 0.28688 & 0.31364 & 0.13339 & 0.29791 \\
\hline SLOVAK R. & 0.29292 & 0.31113 & 0.31416 & 0.29521 & 0.31028 & 0.21342 & 0.32807 \\
\hline SLOVENIA & 0.29068 & 0.32417 & 0.31634 & 0.32268 & 0.33021 & 0.45353 & 0.31399 \\
\hline
\end{tabular}

The next step in the TOPSIS method is to find the ideal and negative ideal variants that are later used to determine their distance from the variant under consideration. In Table 2, the results of the TOPSIS method are presented for the case when the considered criteria are equivalent to each other and each has a weight equal to $1 / 7$. In this case, Estonia is closest to the ideal variant, followed by Malta and Slovenia. Hungary is at the tail end of this table.

Tab. 2 - TOPSIS, equal weights, 2018. Source: own research

\begin{tabular}{|l|l|l|l|l|}
\hline Country & $\mathrm{d}_{\mathrm{i}}^{+}$ & $\mathrm{d}_{\mathrm{i}}{ }^{-}$ & $\mathrm{c}_{\mathrm{i}}$ & Rank \\
\hline CYPRUS & 0.069347 & 0.010709 & 0.133764 & 9 \\
\hline CZECH R. & 0.012675 & 0.0624 & 0.831164 & 4 \\
\hline ESTONIA & 0.006791 & 0.070625 & 0.912283 & 1 \\
\hline HUNGARY & 0.07404 & 0.003962 & 0.050789 & 10 \\
\hline LATVIA & 0.065599 & 0.013154 & 0.167025 & 8 \\
\hline LITHUAN. & 0.039473 & 0.036358 & 0.47946 & 5 \\
\hline MALTA & 0.007915 & 0.073663 & 0.902975 & 2 \\
\hline POLAND & 0.055072 & 0.019952 & 0.265939 & 7 \\
\hline SLOVAK R. & 0.043814 & 0.031487 & 0.418147 & 6 \\
\hline SLOVENIA & 0.013194 & 0.065574 & 0.832494 & 3 \\
\hline
\end{tabular}

Table 3 shows the order of the countries when the criteria do not have equal weights; the weights are calculated by the entropy method, which depends on the input data.

In this case, Malta, Estonia and Slovenia are still in the top three positions, but in contrast to the case with the same weights, Malta and Estonia exchanged their seats. Hungary remains in last place. 
Tab. 3 - TOPSIS, Entropy, 2018. Source: own research

\begin{tabular}{|l|l|l|l|l|}
\hline Country & $\mathrm{d}_{\mathrm{i}}^{+}$ & $\mathrm{d}_{\mathrm{i}}^{-}$ & $\mathrm{c}_{\mathrm{i}}$ & Rank \\
\hline CYPRUS & 0.46875 & 0.026045 & 0.052637 & 9 \\
\hline CZECH R. & 0.078125 & 0.416667 & 0.842105 & 4 \\
\hline ESTONIA & 0.026042 & 0.46875 & 0.947368 & 2 \\
\hline HUNGARY & 0.494792 & 0.000201 & 0.000407 & 10 \\
\hline LATVIA & 0.442708 & 0.052085 & 0.105266 & 8 \\
\hline LITHUAN. & 0.260417 & 0.234375 & 0.473684 & 5 \\
\hline MALTA & 0.000283 & 0.494792 & 0.999429 & 1 \\
\hline POLAND & 0.364584 & 0.130208 & 0.263158 & 7 \\
\hline SLOVAKR. & 0.286459 & 0.208333 & 0.421052 & 6 \\
\hline SLOVENIA & 0.052085 & 0.442708 & 0.894734 & 3 \\
\hline
\end{tabular}

If the WSA method and the same weights of criteria are used for the input data for the given year 2018, then the order is as follows: Estonia is d first, followed by the Czech Republic and Malta. Compared with the TOPSIS method, the Czech Republic came in the first place instead of Slovenia. However, even in this case, Hungary is in the last (10th) place.

Tab. 4 - WSA, equal weights, 2018. Source: own research

\begin{tabular}{|l|l|l|l|l|l|l|l|l|l|}
\hline Country & $\mathrm{K} 1$ & $\mathrm{~K} 2$ & $\mathrm{~K} 3$ & $\mathrm{~K} 4$ & $\mathrm{~K} 5$ & $\mathrm{~K} 6$ & $\mathrm{~K} 7$ & $\mathrm{u}_{\mathrm{i}}$ & Rank \\
\hline CYPRUS & 0.214 & 0.188 & 0.430 & 0.712 & 0.586 & 0.053 & 1.000 & 0.455 & 6 \\
\hline CZECH R. & 0.671 & 1.000 & 0.718 & 0.811 & 0.867 & 0.842 & 0.420 & 0.761 & 2 \\
\hline ESTONIA & 1.000 & 0.942 & 1.000 & 1.000 & 0.681 & 0.947 & 0.024 & 0.799 & 1 \\
\hline HUNGARY & 0.136 & 0.000 & 0.000 & 0.402 & 0.144 & 0.000 & 0.106 & 0.113 & 10 \\
\hline LATVIA & 0.629 & 0.275 & 0.904 & 0.214 & 0.008 & 0.105 & 0.237 & 0.339 & 8 \\
\hline LITHUAN. & 0.750 & 0.406 & 0.942 & 0.000 & 0.422 & 0.474 & 0.615 & 0.516 & 5 \\
\hline MALTA & 0.264 & 0.652 & 0.782 & 0.976 & 0.000 & 1.000 & 0.988 & 0.666 & 3 \\
\hline POLAND & 0.264 & 0.565 & 0.477 & 0.052 & 0.319 & 0.263 & 0.000 & 0.277 & 9 \\
\hline SLOVAK R. & 0.036 & 0.362 & 0.633 & 0.181 & 0.181 & 0.421 & 0.764 & 0.368 & 7 \\
\hline SLOVENIA & 0.000 & 0.768 & 0.665 & 0.609 & 1.000 & 0.895 & 0.408 & 0.621 & 4 \\
\hline
\end{tabular}

To complete this analysis according to the preselected methods, we also need to apply the WSA method for the case of weights obtained by the entropy method. The results are given in Table 5 . In this case, the top three countries are in the same three spots according to the TOPSIS method, namely, Malta, Estonia and Slovenia. Hungary remains in the last position.

Tab. 5 - WSA, Entropy, 2018. Source: own research

\begin{tabular}{|l|l|l|l|l|l|l|l|l|l|}
\hline Country & $\mathrm{K} 1$ & $\mathrm{~K} 2$ & $\mathrm{~K} 3$ & $\mathrm{~K} 4$ & $\mathrm{~K} 5$ & $\mathrm{~K} 6$ & $\mathrm{~K} 7$ & $\mathrm{u}_{\mathrm{i}}$ & Rank \\
\hline CYPRUS & 0.214 & 0.188 & 0.430 & 0.712 & 0.586 & 0.053 & 1.000 & 0.064 & 9 \\
\hline CZECH R. & 0.671 & 1.000 & 0.718 & 0.811 & 0.867 & 0.842 & 0.420 & 0.839 & 4 \\
\hline
\end{tabular}




\begin{tabular}{|l|l|l|l|l|l|l|l|l|l|}
\hline ESTONIA & 1.000 & 0.942 & 1.000 & 1.000 & 0.681 & 0.947 & 0.024 & 0.945 & 2 \\
\hline HUNGARY & 0.136 & 0.000 & 0.000 & 0.402 & 0.144 & 0.000 & 0.106 & 0.004 & 10 \\
\hline LATVIA & 0.629 & 0.275 & 0.904 & 0.214 & 0.008 & 0.105 & 0.237 & 0.114 & 8 \\
\hline LITHUAN. & 0.750 & 0.406 & 0.942 & 0.000 & 0.422 & 0.474 & 0.615 & 0.474 & 5 \\
\hline MALTA & 0.264 & 0.652 & 0.782 & 0.976 & 0.000 & 1.000 & 0.988 & 0.993 & 1 \\
\hline POLAND & 0.264 & 0.565 & 0.477 & 0.052 & 0.319 & 0.263 & 0.000 & 0.262 & 7 \\
\hline SLOVAK R. & 0.036 & 0.362 & 0.633 & 0.181 & 0.181 & 0.421 & 0.764 & 0.419 & 6 \\
\hline SLOVENIA & 0.000 & 0.768 & 0.665 & 0.609 & 1.000 & 0.895 & 0.408 & 0.885 & 3 \\
\hline
\end{tabular}

For 2020, the input data were subjected to the same two methods of multicriteria analysis as they were for 2018. Table 6 represents the normalised criterion matrix for the given year. For the analysis to be beneficial, the same countries and the same criteria were considered in 2020 as they were for the 2018 evaluation. The methods for determining the weights of these criteria and the methods for determining the order of countries were TOPSIS and WSA.

Tab. 6 - Normalised criterion matrix, 2020. Source: own research

\begin{tabular}{|l|l|l|l|l|l|l|l|}
\hline Country & K1 & K2 & K3 & K4 & K5 & K6 & K7 \\
\hline CYPRUS & 0.3114 & 0.30731 & 0.305015 & 0.33247 & 0.32267 & 0.26078 & 0.3091 \\
\hline CZECH R. & 0.3322 & 0.32768 & 0.3170665 & 0.35191 & 0.32286 & 0.34102 & 0.3387 \\
\hline ESTONIA & 0.3451 & 0.32814 & 0.3332731 & 0.35147 & 0.32498 & 0.50150 & 0.3139 \\
\hline HUNGARY & 0.2949 & 0.30129 & 0.2746802 & 0.30233 & 0.30174 & 0 & 0.3039 \\
\hline LATVIA & 0.3194 & 0.31009 & 0.3336886 & 0.29927 & 0.30982 & 0.28084 & 0.2938 \\
\hline LITHUAN. & 0.3407 & 0.31657 & 0.3390908 & 0.28522 & 0.31273 & 0.24072 & 0.3000 \\
\hline MALTA & 0.3087 & 0.31703 & 0.3174821 & 0.33771 & 0.31615 & 0.42126 & 0.3373 \\
\hline POLAND & 0.3069 & 0.31888 & 0.3050155 & 0.29083 & 0.31403 & 0.20060 & 0.2905 \\
\hline SLOVAK R. & 0.2967 & 0.30916 & 0.3141577 & 0.28901 & 0.30967 & 0.22066 & 0.3258 \\
\hline SLOVENIA & 0.3011 & 0.32490 & 0.3178976 & 0.31238 & 0.32666 & 0.40120 & 0.3435 \\
\hline
\end{tabular}

The results of the TOPSIS method with the same weights show that the elite ranking of the countries seems to be relatively stable (Table 7). Again, the same three countries are at the forefront as they were applying the same method in the previous reporting period. Therefore, it is more interesting to observe how the other countries that fall somewhere in the middle of the ranking had changed. Compared with 2018, countries such as Latvia and Cyprus improved their position. In contrast, Lithuania, Poland and Slovakia moved down two places in the ranking.

Tab. 7 - TOPSIS, equal weights, 2020. Source: own research

\begin{tabular}{|l|l|l|l|l|}
\hline Country & $\mathrm{d}_{\mathrm{i}}^{+}$ & $\mathrm{d}_{\mathrm{i}}^{-}$ & $\mathrm{c}_{\mathrm{i}}$ & Rank \\
\hline CYPRUS & 0.03564 & 0.03840 & 0.51860 & 6 \\
\hline CZECH R. & 0.02323 & 0.05099 & 0.68701 & 4 \\
\hline ESTONIA & 0.00431 & 0.07335 & 0.94446 & 1 \\
\hline HUNGARY & 0.07334 & 0.00310 & 0.04057 & 10 \\
\hline
\end{tabular}




\begin{tabular}{|l|l|l|l|l|}
\hline LATVIA & 0.03357 & 0.04123 & 0.55120 & 5 \\
\hline LITHUAN. & 0.03904 & 0.03632 & 0.48194 & 7 \\
\hline MALTA & 0.01333 & 0.06143 & 0.82169 & 2 \\
\hline POLAND & 0.04516 & 0.02921 & 0.39272 & 9 \\
\hline SLOVAK R. & 0.04208 & 0.03246 & 0.43551 & 8 \\
\hline SLOVENIA & 0.01691 & 0.05848 & 0.77567 & 3 \\
\hline
\end{tabular}

With almost identical data to that shown in Table 7, Table 8 presents the results of the TOPSIS method for the case of weights obtained by the entropy method. A very small difference occurred in the first two places, where the countries of Estonia and Malta exchanged positions. Even with this choice of weights, the countries of Latvia and Cyprus improved their position compared to 2018, while the remaining countries either retained their position or worsened.

Tab. 8 - TOPSIS, Entropy, 2020. Source: own research

\begin{tabular}{|l|l|l|l|l|}
\hline Country & $\mathrm{d}_{\mathrm{i}}{ }^{+}$ & $\mathrm{d}_{\mathrm{i}}^{-}$ & $\mathrm{c}_{\mathrm{i}}$ & Rank \\
\hline CYPRUS & 0.03564 & 0.03840 & 0.51860 & 6 \\
\hline CZECH R. & 0.02323 & 0.05099 & 0.68701 & 4 \\
\hline ESTONIA & 0.00431 & 0.07335 & 0.94446 & 1 \\
\hline HUNGARY & 0.07334 & 0.00310 & 0.04057 & 10 \\
\hline LATVIA & 0.03357 & 0.04123 & 0.55120 & 5 \\
\hline LITHUAN. & 0.03904 & 0.03632 & 0.48194 & 7 \\
\hline MALTA & 0.01333 & 0.06143 & 0.82169 & 2 \\
\hline POLAND & 0.04516 & 0.02921 & 0.39272 & 9 \\
\hline SLOVAK R. & 0.04208 & 0.03246 & 0.43551 & 8 \\
\hline SLOVENIA & 0.01691 & 0.05848 & 0.77567 & 3 \\
\hline
\end{tabular}

For 2020, the weighted sum method confirmed that Estonia, Slovenia and Malta represent the set of variants that closest to the ideal variant with the best results according to each of the above criteria. The WSA also confirms that the negative ideal solution option achieving the worst results was Hungary. A total of six out of ten countries maintained their position compared with those of 2018. These are Cyprus, the Czech Republic, Estonia, Hungary, Lithuania and Poland. Latvia and Slovenia moved up one place, while Malta and Slovakia went down one place (Table 9).

Tab. 9 - WSA, equal weights, 2020. Source: own research

\begin{tabular}{|l|l|l|l|l|l|l|l|l|l|}
\hline Country & $\mathrm{K} 1$ & $\mathrm{~K} 2$ & $\mathrm{~K} 3$ & $\mathrm{~K} 4$ & $\mathrm{~K} 5$ & $\mathrm{~K} 6$ & $\mathrm{~K} 7$ & $\mathrm{u}_{\mathrm{i}}$ & $\mathrm{R}$ ank \\
\hline CYPRUS & 0.327 & 0.224 & 0.471 & 0.709 & 0.840 & 0.520 & 0.351 & 0.492 & 6 \\
\hline CZECH R. & 0.743 & 0.983 & 0.658 & 1.000 & 0.848 & 0.680 & 0.910 & 0.832 & 2 \\
\hline ESTONIA & 1.000 & 1.000 & 0.910 & 0.993 & 0.933 & 1.000 & 0.441 & 0.897 & 1 \\
\hline HUNGARY & 0.000 & 0.000 & 0.000 & 0.257 & 0.000 & 0.000 & 0.252 & 0.073 & 10 \\
\hline LATVIA & 0.487 & 0.328 & 0.916 & 0.211 & 0.324 & 0.560 & 0.063 & 0.413 & 7 \\
\hline
\end{tabular}




\begin{tabular}{|l|l|l|l|l|l|l|l|l|l|}
\hline LITHUAN. & 0.912 & 0.569 & 1.000 & 0.000 & 0.441 & 0.480 & 0.180 & 0.512 & 5 \\
\hline MALTA & 0.274 & 0.586 & 0.665 & 0.787 & 0.578 & 0.840 & 0.883 & 0.659 & 4 \\
\hline POLAND & 0.239 & 0.655 & 0.471 & 0.084 & 0.493 & 0.400 & 0.000 & 0.335 & 9 \\
\hline SLOVAK R. & 0.035 & 0.293 & 0.613 & 0.057 & 0.318 & 0.440 & 0.667 & 0.346 & 8 \\
\hline SLOVENIA & 0.124 & 0.879 & 0.671 & 0.407 & 1.000 & 0.800 & 1.000 & 0.697 & 3 \\
\hline
\end{tabular}

To complement the previous analysis, the results of the weighted sum method for the weights of the criteria calculated by the entropy method remain to be evaluated. These results are shown in Table 10.

The normalised weights of the criteria gained by the entropy method for 2020 are $(0,009131817$; 002344206;00994316;0190459;001830265;94700027;0,01070436).

This analysis and its results confirmed the clear leadership of Estonia and Malta. According to all seven of the indicators that were used in this multicriteria analysis, these countries clearly performed best when compared with the other countries evaluated. The Czech Republic and Slovenia fall jointly behind these two countries. And as in all of the previous evaluations, Slovakia, Poland and Hungary took the last places (Table 10).

Tab. 10 - WSA, Entropy, 2020. Source: own research

\begin{tabular}{|l|l|l|l|l|l|l|l|l|l|}
\hline Country & $\mathrm{K} 1$ & $\mathrm{~K} 2$ & $\mathrm{~K} 3$ & $\mathrm{~K} 4$ & $\mathrm{~K} 5$ & $\mathrm{~K} 6$ & $\mathrm{~K} 7$ & $\mathrm{u}_{\mathrm{i}}$ & Rank \\
\hline CYPRUS & 0.327 & 0.224 & 0.471 & 0.709 & 0.840 & 0.520 & 0.351 & 0.519 & 6 \\
\hline CZECH R. & 0.743 & 0.983 & 0.658 & 1.000 & 0.848 & 0.680 & 0.910 & 0.690 & 4 \\
\hline ESTONIA & 1.000 & 1.000 & 0.910 & 0.993 & 0.933 & 1.000 & 0.441 & 0.993 & 1 \\
\hline HUNGARY & 0.000 & 0.000 & 0.000 & 0.257 & 0.000 & 0.000 & 0.252 & 0.008 & 10 \\
\hline LATVIA & 0.487 & 0.328 & 0.916 & 0.211 & 0.324 & 0.560 & 0.063 & 0.550 & 5 \\
\hline LITHUAN. & 0.912 & 0.569 & 1.000 & 0.000 & 0.441 & 0.480 & 0.180 & 0.477 & 7 \\
\hline MALTA & 0.274 & 0.586 & 0.665 & 0.787 & 0.578 & 0.840 & 0.883 & 0.831 & 2 \\
\hline POLAND & 0.239 & 0.655 & 0.471 & 0.084 & 0.493 & 0.400 & 0.000 & 0.390 & 9 \\
\hline SLOVAK R. & 0.035 & 0.293 & 0.613 & 0.057 & 0.318 & 0.440 & 0.667 & 0.433 & 8 \\
\hline SLOVENIA & 0.124 & 0.879 & 0.671 & 0.407 & 1.000 & 0.800 & 1.000 & 0.788 & 3 \\
\hline
\end{tabular}

Multicriteria analysis has an undeniably important purpose in situations where the decision to choose the best variant or to rank variants according to their quality and importance, is difficult due to the ambiguity of the position of the variants with respect to the conditions or criteria. This analysis helps us find a compromise variant, and when used correctly, it also makes it possible to compare the variants to each other, which is also one of the results of this work. On the one hand, countries were identified that maintained their position in both periods under review, either at the top of the table or at the end. On the other hand, this comparison showed how the countries were able to cope with the current conditions and how effective their decisions and reforms were during the period under review. All of this is reflected in their position, which can be seen in the results of the multicriteria analysis in Fig. 1. The results shown in this figure declare the position of selected countries in two monitoring periods, namely, in 2018 and 2020. 


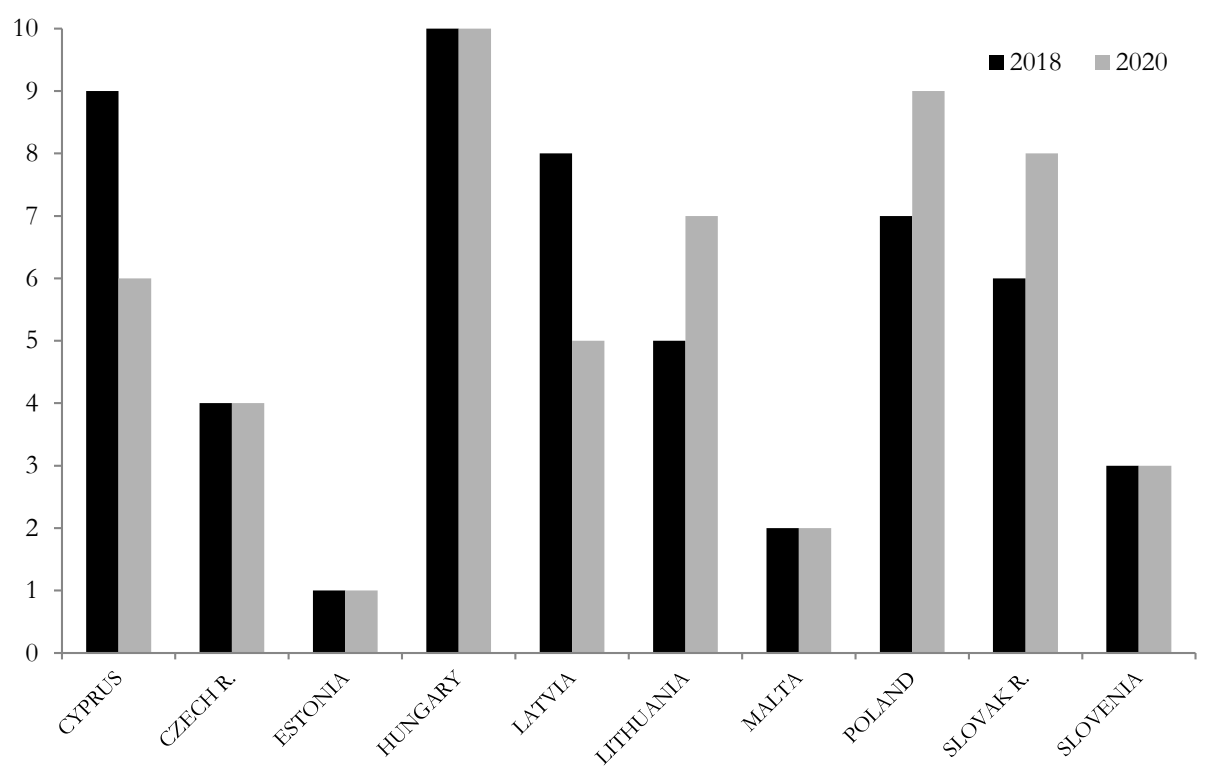

Fig. 1 - The rank of the countries in 2018 and 2020. Source: own research

A good business environment is generally considered to be a key condition that affects the longterm competitiveness and growth of any market economy. According to several specialised international evaluations, the business environments in selected countries are improving with different heartbeats. According to our study, Slovakia lags far behind other observed countries. This study compares the effectiveness of countries that joined the EU at the same time and were therefore on the same starting line in terms of sustainable economic growth. The highest values of the Doing Business indicator were reached by the Baltic countries - Estonia, Lithuania, and Latvia. The lowest values were recorded in Malta. The results of the Economic Freedom indicator are similar to that of the Doing Business indicator, but the differences between countries are smaller. Based on the performed multicriteria analysis, we came to the following conclusions. By far, the best country was Estonia, which maintained its leading position within the evaluated countries. Malta took the second place in both years, and Slovenia came in the third place. These countries were able to make decisions that provided them with the best results according to indicators selected as important factors in describing the country's situation. The Czech Republic maintained a stable fourth place. There was a significant change for Lithuania and Latvia. While Latvia improved by three places in two years, moving from the eighth to the fifth place, Lithuania failed to maintain the fifth place in 2018 and dropped to the seventh place. Another significant improvement is evident for Cyprus, which finished ninth in 2018 but managed to move up three places to the sixth place in two years. On the other hand, what succeeded in Cyprus did not succeed in the Slovak Republic and Poland. The latter two countries were unable to fight for top positions; on the contrary, they moved two places down. The Slovak Republic fell from the sixth to the eighth place, and Poland moved from the seventh to the penultimate ninth place. Hungary was in the last (tenth) place in both monitored periods. Many 
studies have demonstrated that developing the business environment is the most important source of competitiveness and job creation (Bruothova, 2016; Mura, 2019), and economic growth is the willingness and ability to adapt to changing market conditions. The quality of the business environment is also reflected in other economic and social aspects, such as countries' innovation performance (Herzer \& Nagel, 2020), knowledge transfer (Bar \& Leukhina, 2010), technological progress (Gehringer \& Prettner, 2019), the supply labour force (Jiang et al., 2019), and poverty (Kim, 2018). We unequivocally state that the conclusions of the individual studies clearly agree with the results of the present study. Aspects such as the administrative burden of entrepreneurs, the tax burden, the bureaucracy of public procurement, insufficient electronification of businessrelated processes, insufficient support for start-up entrepreneurs, and corruption are difficult to overcome. It is necessary to look to the example of countries that are in top positions, such as Singapore, where $75 \%$ of the tax liability was waived in 2017 so that the tax system favoured start-ups (Ying et al., 2020).

\section{CONCLUSION}

Business has an important role in the development of an economy, and the business environment reflects the quality of economic conditions and the economic direction of a country. In the current era of globalisation, it is very important to look at the issue discussed here in terms of economic growth. Comparing the business environment of states is very important in terms of evaluating the quality of life and the conditions of running a business in a particular country. This study compares the effectiveness of countries that joined the EU at the same time and thus were on the same starting line in terms of sustainable economic growth. Based on the performed multicriteria analysis, the following conclusions were obtained. The best conditions for a good business environment were provided by Estonia, which maintained its first place in both time periods. The top three places were completed by Malta and Slovenia, which took the second and third positions in both 2018 and 2020. These countries were followed by the Czech Republic, which maintained fourth place. Latvia and Cyprus improved their positions by three places compared with 2018, with Latvia moving from eighth to fifth place and Cyprus moving from the ninth to the sixth place. In contrast, the countries of Lithuania, Slovakia and Poland each fell 3 places. Slovakia fell from the sixth to the eighth place, Lithuania ended in the seventh place, and Poland ended in the ninth place. The results end with Hungary, which remained in last (tenth) place. Future research on this topic will focus on how countries have coped with the COVID-19 pandemic by analysing the consequences of the measures that each country implemented to ensure the country's stability, the protection of the health of its inhabitants, and the quality of the business environment. The presented research study will serve as a basis for comparing the achieved results.

\section{References}

1. Akram, M., Dudek, W. A., \& Ilyas, F. (2019). Group decision-making based on Pythagorean fuzzy TOPSIS method. International Journal of Intelligent Systems, 34 (7), 1455-1475. https://doi.org/10.1002/int.22103 
2. Altuntas, S., Cinar, O., \& Kaynak, S. (2018). Relationships among advanced manufacturing technology, innovation, export, and firm performance: Empirical evidence from Turkish manufacturing companies. Kybernetes, 47 (9), 1836-1856.

https://doi.org/10.1108/K-10-2017-0380

3. Anyakoha, C. (2019). Job analysis as a tool for improved organizational performance of SMEs in Lagos, Nigeria. Central European Journal of Labour Law and Personnel Management, 2 (1), 7-16. https://doi.org/10.33382/cejllpm.2019.02.0

4. Bar, M., \& Leukhina, O. (2010). The role of mortality in the transmission of knowledge. Journal of Economic Growth, 15 (4), 291-321. http:/dx.doi.org/10.1007/s10887-010-9059-5

5. Belas, J., Gavurova, B., Kubalek, J., \& Kubak, M. (2020). Discrepancies in perception and evaluation of macroenvironment - sectoral analysis. Journal of Business Economics and Management, 21 (4), 1072-1092. https://doi.org/10.3846/jbem.2020.12274

6. Bertelli, A. (2016). Who Are the Policy Workers, and What Are They Doing? 'Citizen's Heuristics and Democratic Accountability in Complex Governance. Public Performance Management Review, 40 (2), 208234. https://doi.org/10.1080/15309576.2016.1180306

7. Bjørnskov, C., \& Foss, N.J. (2016). Institutions, Entrepreneurship, and Economic Growth: What Do We Know and What Do We Still Need to Know? Academy of Management Perspectives, 30 (3), 292-315. https://doi.org/10.5465/amp.2015.0135

8. Block, J., \& Fisch, C. (2019). Extending the focus of management review quarterly: one year later. Management Review Quarterly, 69, 1-2. https://doi.org/10.1007/s11301-019-00153-w

9. Bruothová, M. (2016). Selected characteristics of business environment in Visegrad region. Central European Journal of Management, 3(1), https://doi.org/10.5817/CEJM2016-1-3

10. Chen, P. (2019). Effects of normalization on the entropy-based TOPSIS method. Expert Systems with Applications, 136, 33-41. https://doi.org/10.1016/j.eswa.2019.06.035

11. Chen, S. J., Hwang, C. L. (1992). Fuzzy Multiple Attribute Decision Making Methods. In: Fuzzy Multiple Attribute Decision Making. Lecture Notes in Economics and Mathematical Systems, 375. Springer, Berlin, Heidelberg. https://doi.org/10.1007/978-3-642-46768-4_5

12. Čižo, E., Lavrinenko, O., \& Ignatjeva, S. (2020). Analysis of the relationship between financial development and economic growth in the EU countries. Insights into Regional Development, 2 (3), 645-660. https://doi.org/10.9770/IRD.2020.2.3(3)

13. Durda, L., \& Kljucnikov, A. (2019). Social networks in entrepreneurial startups development. Economics \& Sociology, 12 (3), 192-208. https://doi.org/10.14254/2071-789X.2019/12-3/13

14. Feneri, A., Vagiona, D., \& Karanikolas, N. (2015). Multi-criteria decision making to measure quality of life: an integrated approach for implementation in the urban area of Thessaloniki, Greece. Quality of Life, 10 (4), 573-587. https://doi.org/10.1007/s11482-014-9335-1

15. Fuentelsaz, L., González, C., Maícas, J. P., \& Montero, J. (2015). How different formal institutions affect opportunity and necessity entrepreneurship. BRQ Business Research Quarterly, 18, 246-258. https://doi.org/10.1016/j.brq.2015.02.001

16. Gehringer, A., \& Prettner, K. (2019). Longevity and technological change. Macroeconomic Dynamics, 23 (4), 1471-1503. http:/dx.doi.org/10.1017/\$1365100517000293 
17. Halasi, D., Schwarcz, P., Mura, L., \& Roháčiková, O. (2019). The impact of EU support resources on business success of family-owned businesses. Potravinarstvo Slovak Journal of Food Sciences, 13 (1), 846-853. https://doi.org/10.5219/1167

18. Hao, J., Li, C., Yuan, R. Ahmed, M., Khan, M. A., \& Oláh, J. (2020). The Influence of the Knowledge-Based Network Structure Hole on Enterprise Innovation Performance. The Threshold Effect of R\&D Investment Intensity. Sustainability, 12 (15), 6155. https://doi.org/10.3390/su12156155

19. Herzer, D., \& Nagel, K. (2019). The impact of adult and non-adult mortality on development: two centuries evidence from a panel of industrial countries. Journal of Policy Modeling, 41 (2), 352-371. http:/dx.doi.org/10.1016/j.jpolmod.2019.02.008

20. Jiang, J., Huang, W., Wang, Z., \& Zhang, G. (2019). The effect of health on labour supply of rural elderly people in China an empirical analysis using CHARLS data. International Journal of Environmental Research and Public Health, 16 (7), 1195. http://dx.doi.org/10.3390/ijerph16071195

21. Kasseeah, H. (2016). Investigating the impact of entrepreneurship on economic development: a regional analysis. Journal of Small Business and Enterprise Development, 23 (3), 896-916. https://doi.org/10.1108/JSBED-09-2015-0130

22. Kim, Y. (2018). Eliminating poverty in the 21st century the role of health and human capital. JAMA-Journal of the American Medical Association, 320 (14), 1427-1428. https://doi.org/10.1001/jama.2018.13709

23. Kotaskova, A., \& Rozsa, Z. (2018). The impact of selected factors on the quality of business environment assessment in the Czech Republic and the Slovak Republic. International Journal of Entrepreneurial Knowledge, 6 (2), 71-80. https://doi.org/10.2478/IJEK-2018-0015

24. Lechman, E. (2019). Still 'few, slow and 'low'? On the female dimension of technology, labour markets and economic activity: evidence for the period of 1990-2017. Economics and Sociology, 12 (1), 11-38. https://doi.org/10.14254/2071-789X.2019/12-1/1

25. Lewandowska, A., \& Stopa, M. (2018). SMEs innovativeness and institutional support system: the local experiences in qualitative perspective. Polish case study. Oeconomia Coprnicana, 9 (2), 333-351. https://doi.org/10.24136/oc.2018.017

26. Li, C., Pervaiz, K., Asif Khan, M., Ur Rehman, R., \& Oláh, J. (2019). On the Asymmetries of Sovereign Credit Rating Announcements and Financial Market Development in the European Region. Sustainability, 11 (23), 6636, https://doi.org/10.3390/su11236636

27. Li, H., Terjesen, S., \& Umans, T. (2020). Corporate governance in entrepreneurial firms: a systematic review and research agenda. Small Business Economics, 54, 43-74. https://doi.org/10.1007/s11187-018-0118-1

28. Liang, D., \& Xu, Z. (2017). The new extension of TOPSIS method for multiple criteria decision making with hesitant Pythagorean fuzzy sets. Applied Soft Computing, 60, 167-179. https://doi.org/10.1016/j.asoc.2017.06.034

29. Mankiw, N. G. (2020). Principles of economics. Boston: Cengage Learning.

30. Marti, L., \& Puertas, R. (2021). European 'countries' vulnerability to COVID-19: multicriteria decision-making techniques. Economic Research-Ekonomska Istraživanja, 1-12. https://doi.org/10.1080/1331677X.2021.1874462 
31. Metzker, Z., \& Streimikis, J. (2020). CSR activities in the Czech SME segment. International Journal of Entrepreneurial Knowledge, 8 (1), 49-64. https://doi.org/10.37335/ijek.v8i2.101

32. Mrożewski, M., \& Kratzer, J. (2017). Entrepreneurship and country-level innovation: investigating the role of entrepreneurial opportunities. The Journal of Technology Transfer, 42 (5), 1125-1142, https://doi.org/10.1007/s10961-016-9479-2

33. Mura, L. (2019). Entrepreneurship internationalization-case of Slovak family businesses. Ad Alta: Journal of Interdisciplinary Research, 9(1).

34. Mura, L., \& Mazák, M. (2018). Innovative activities of family SMEs: case study of the Slovak regions. On-line Journal Modelling the New Europe, 27, 132-147.

https://doi.org/10.24193/OJMNE.2018.27.06

35. Noja, G. G., Cristea, M., Sirghi, N., Hategan, C.-D., \& D’Anselmi, P. (2019). Promoting Good Public Governance and Environmental Support for Sustainable Economic Development. International Journal of Environmental Research and Public Health, 16, 4940. https://doi.org/10.3390/ijerph16244940

36. OECD (2021). OECD.stat. Retrieved January 1, 2021 from https:/ stats.oecd.org/\#

37. Remeikiene, R., Belas, J., Kliestik, T., \& Smrcka, L. (2020). Quantitative assessment of dynamics of economic development in the countries of the European Union. Technological and Economic Development of Economy, 26 (4), 933-946. https://doi.org/10.3846/tede.2020.12892

38. Triantaphyllou, E. (2000). Multi-criteria decision-making methods. In: Multi-criteria decisionmaking methods: A comparative study, Boston: Kluwer Academic Publisher.

39. Ture, H., Dogan, S., \& Kocak, D. (2019). Assessing Euro 2020 strategy using multi-criteria decision-making methods: VIKOR and TOPSIS. Social Indicators Research, 142 (2), 645-665. https://doi.org/10.1007/s11205-018-1938-8

40. Urbano, D., \& Aparicio, S. (2016). Entrepreneurship capital types and economic growth: International evidence. Technological Forecasting and Social Change, 102, 34-44. https://doi.org/10.1016/j.techfore.2015.02.018

41. Vakilipour, S., Sadeghi-Niaraki, A., Ghodousi, M., Choi, S. M. (2021). Comparison between Multi-Criteria Decision-Making Methods and Evaluating the Quality of Life at Different Spatial Levels. Sustainability, 13 (7), 4067. https://doi.org/10.3390/su13074067

42. Virglerova, Z., Khan, M. A., Martinkute-Kauliene, R., \& Kovács, S. (2020). The Internationalization of SMEs in Central Europe and Its Impact on Their Methods of Risk Management. Amfiteatru Economic, 22 (55), 792-807.

https://doi.org/10.24818/EA/2020/55/792

43. Ying, S., Sindakis, S., Aggarwal, S., Chen, C., \& Su, J. (2020). Managing big data in the retail industry of Singapore: Examining the impact on customer satisfaction and organizational performance. European Management Journal, 39 (3), 390-400.

https://doi.org/10.1016/j.emj.2020.04.001

44. Zauskova, A., \& Reznickova, M. (2020). SoLoMo marketing as a global tool for enhancing awareness of eco-innovations in Slovak business environment. Equilibrium. Quarterly Journal of Economics and Economic Policy, 15 (1), 133-150. https://doi.org/10.24136/eq.2020.007 
45. Zeng, S., Chen, S. M., \& Fan, K. Y. (2020). Interval-valued intuitionistic fuzzy multiple attribute decision making based on nonlinear programming methodology and TOPSIS method. Information Sciences, 506, 424-442. https://doi.org/10.1016/j.ins.2019.08.027

\section{Contact information}

doc. RNDr. Zuzana Hajduova, PbD., MSc. mim. prof.

University of Economics in Bratislava

Faculty of Business Management

Department of Business Finance

Slovakia

E-mail:zuzana.hajduova@euba.sk

ORCID: 0000-0002-9381-776X

RNDr. Jana Coronicova Hurajova, PhD.

University of Economics in Bratislava

Faculty of Business Administration based in Košice

Department of Quantitative Methods

Slovakia

E-mail: jana.coronicova@euba.sk

ORCID: 0000-0002-1118-9676

Ing. Marian Smorada, PhD.

University of Economics in Bratislava

Faculty of Business Management

Department of Business Finance

Slovakia

E-mail:marian.smorada@euba.sk

ORCID: 0000-0003-1675-7019

Ing. Ludovit Srenkel, PhD.

University of Žilina

The Institute of Forensic Engineering University of Žilina

Slovakia

E-mail: ludovit.srenkel@usi.sk 